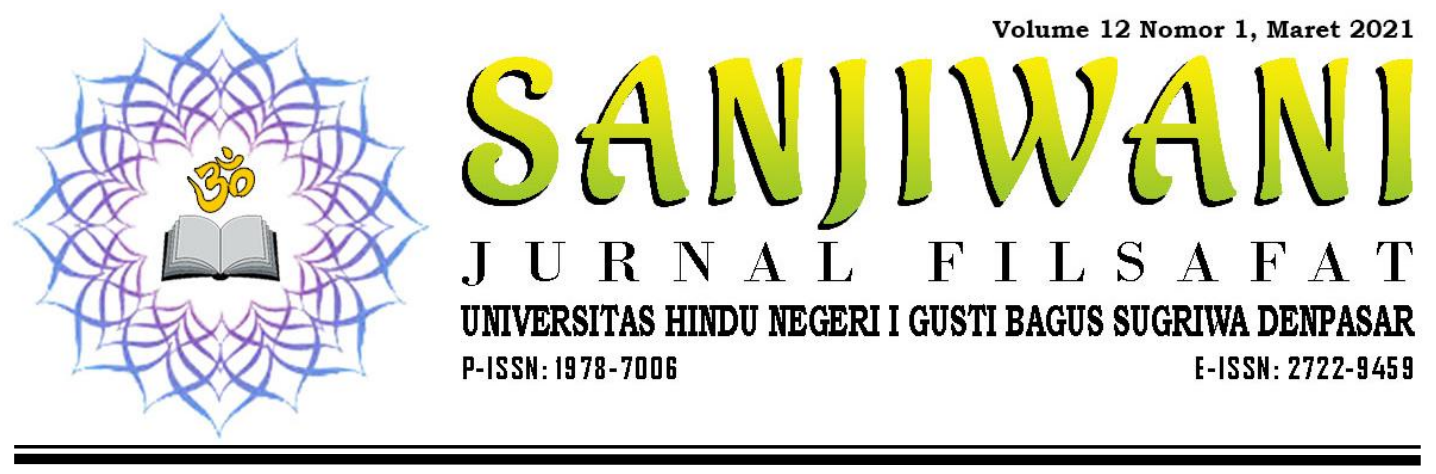

\title{
Mìmāmsā Darśana dan Pengaruhnya terhadap Ajaran Agama Hindu di Bali
}

\author{
I Made Surada \\ Universitas Hindu Negeri I Gusti Bagus Sugriwa Denpasar \\ madesurada67@gmail.com
}

\begin{tabular}{|c|c|}
\hline Keywords: & ABSTRACT \\
\hline $\begin{array}{l}\text { Mìmāmiā Darśana; } \\
\text { Its Influence; Hindu } \\
\text { Religion Teachings } \\
\text { in Bali }\end{array}$ & 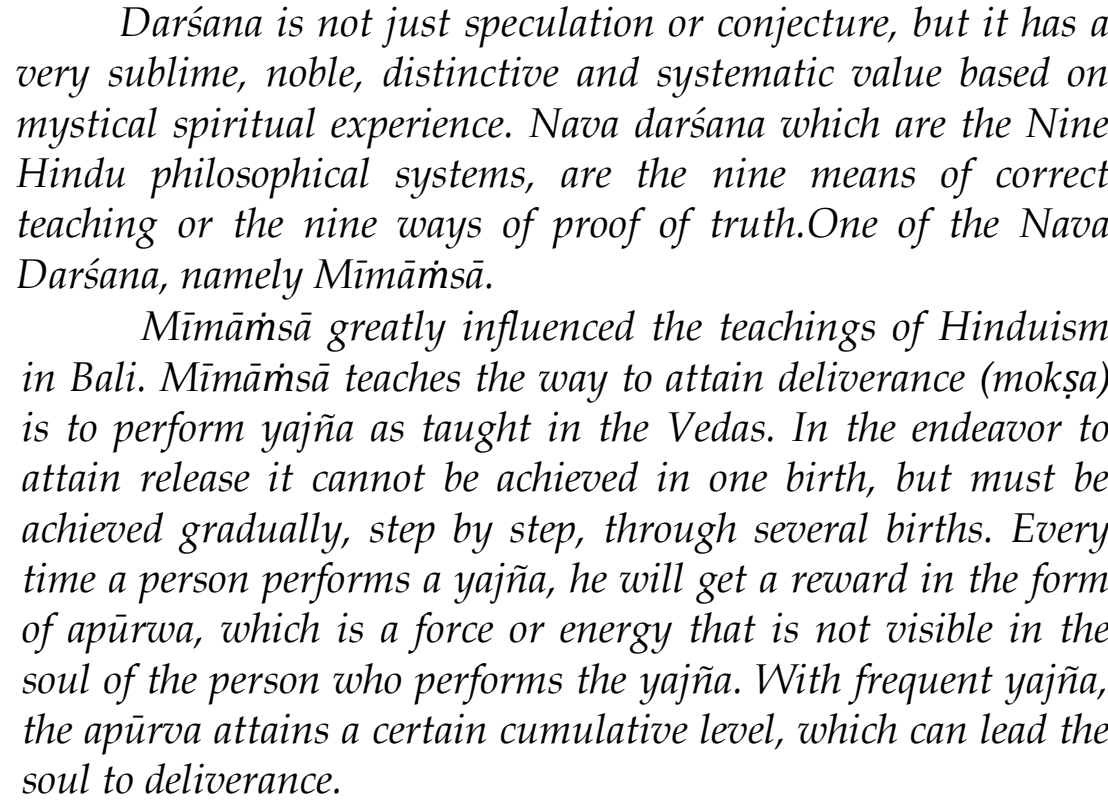 \\
\hline
\end{tabular}

\section{Kata Kunci ABSTRAK}

Mìmāmsā Darśana;

Pengaruhnya;

Darśana bukan hanya merupakan spekulasi atau

Ajaran Agama dugaan belaka, namun ia memiliki nilai yang amat luhur, Hindu Di Bali mulia, khas dan sistematis yang didasarkan oleh pengalaman spiritual mistis. Nava darśana yang merupakan Sembilan sistem filsafat Hindu, merupakan sembilan sarana pengajaran yang benar atau Sembilan cara pembuktian kebenaran. Salah satu dari Nava Darśana, yaitu Mìmāmsā.

Mìmāmsā sangat besar pengaruhnya terhadap ajaran Agama Hindu di Bali. Mìmāmsāa mengajarkan jalan untuk mencapai kelepasan (mokșa) adalah dengan melaksanakan 
yajña seperti yang diajarkan oleh kitab Veda. Dalam usaha mencapai kelepasan tidak mungkin bisa tercapai dalam satu kali kelahiran, melainkan harus dicapai secara berangsur-angsur setingkat demi setingkat melalui beberapa kali kelahiran. Setiap kali orang melakukan yajña maka ia akan memperoleh pahala berupa apūrwa, yaitu suatu tenaga atau daya atau energi yang tidak tampak di dalam jiwa orang yang melakukan yajña. Dengan seringnya orang melakukan yajña, maka apürwa tersebut akan mencapai tingkatan kumulatif tertentu, yang dapat membawa jiwa mencapai kelepasan.

\section{PENDAHULUAN}

Mìmāimsā adalah bagian dari Sad Darśana. Sad darśana merupakan bagian penulisan Hindu yang memerlukan kecerdasan yang tajam, penalaran serta perasaan, karena masalah pokok yang dibahasnya merupakan intisari pemahaman Veda secara menyeluruh di bidang filsafat. Sad darsana juga disebut sebagai filsafat Hindu. Kata Darśana berasal dari akar kata drś yang bermakna "melihat", menjadi kata darśana yang berarti "penglihatan" atau "pandangan". Dalam ajaran filsafat Hindu, Darśana berarti pandangan tentang kebenaran. Sad Darśana berarti Enam pandangan tentang kebenaran, yang mana merupakan dasar dari filsafat Hindu.

Astika (filsafat Hindu) adalah institusi pendidikan filsafat ortodok yang memandang Veda sebagai dasar kemutlakan dalam pengajaran filsafat Hindu,yaitu: Nyāya, Vaiśesika, Sāmkhyā, Yoga, Mìmāmsāa, (juga disebut dengan Pūrva Mìmāmsā), dan Vedānta (juga disebut dengan Uttara Mìmāmsiā) keenam sampradaya ini dikenal dengan istilah Sad Astika Darśana atau Sad Darśana. Di luar keenam Astika diatas, terdapat juga Nastika, pandangan Heterodok yang tidak mengakui otoritas dari Weda, yaitu: Buddha, Jaina dan Carvaka. Meski demikian, ajaran filsafat ini biasanya dipelajari secara formal oleh para pakar, pengaruh dari masing-masing Astika ini dapat dilihat dari sastra-sastra Hindu dan keyakinan yang dipegang oleh pemeluknya dalam kehidupan sehari-hari.

Filsafat Hindu bukan hanya merupakan spekulasi atau dugaan belaka, namun ia memiliki nilai yang amat luhur, mulia, khas dan sistematis yang didasarkan oleh pengalaman spiritual mistis. Sad darśana yang merupakan 6 sistem filsafat Hindu, merupakan 6 sarana pengajaran yang benar atau 6 cara pembuktian kebenaran. Adapun bagian-bagian dari Sad Darsana adalah :

1. Nyaya, pendirinya adalah Gotama dan penekanan ajarannya ialah pada aspek logika.

2. Waiśesika, pendirinya ialah Kanada dan penekanan ajarannya pada pengetahuan yang dapat menuntun seseorang untuk merealisasikan sang diri.

3. Samk $h y \bar{a}$, menurut tradisi pendirinya adalah Kapita. Penekanan ajarannya ialah tentang proses perkembangan dan terjadinya alam semesta.

4. Yoga, pendirinya adalah Patanjali dan penekanan ajarannya adalah pada pengendalian jasmani dan pikiran untuk mencapai Samadhi. 
5. Mìmāmsā (Purva-Mìmāmsāa), pendirinya ialah Jaimini dengan penekanan ajarannya pada pelaksanaan ritual dan susila menurut konsep Veda.

6. Wedānta (Uttara-Mìmāmsāa), kata ini berarti akhir Veda. Vedānta merupakan puncak dari filsafat Hindu. Pendirinya ialah Sankara, Ramanuja, dan Madhwa. Penekanan ajarannya adalah pada hubungan Atma dengan Brahman dan tentang kelepasan (Surada, 2005:9).

Ke-6 bagian-bagian dari Sad Darśana diatas merupakan secara langsung berasal dari kitab-kitab Weda, kalau diibaratkan masing-masing bagian dari Sad Darśana itu merupakan jalan untuk menuju Tuhan. Di mana untuk mencapai Tuhan kita harus melalui salah satu dari keenam jalan tersebut. Memang jalan yang kita lalui berbeda-beda namun setiap jalan mampunyai tujuan yang sama yaitu menghilangkan ketidak tahuan dan pengaruhpengaruhnya berupa penderitaan dan duka cita, serta pencapaian kebebasan, kesempurnaan, kekekalan dan kebahagiaan abadi.

\section{PEMBAHASAN}

\subsection{Mīmāìnsā dan Pendirinya}

Ajaran Mìmāmsā didirikan oleh Maharsi Jaimini, disebut juga dengan nama lain Purwa Mìmāmssā. Kata Mìmāmsā berarti penyelidikan. Penyelidikan sistematis terhadap Veda. Mìmāmsā secara khusus melakukan pengkajian pada bagian Veda: Brahmana dan Kalpasūtra. Sumber ajaran ini tertuang dalam Jaiminiyasūtra. Kitab ini terdiri atas 12 Adhyaya (bab) yang terbagi kedalam 60 pada atau bagian, yang isinya adalah aturan tata upacara menurut Veda.

Rși Jaimini adalah salah seorang murid dari Mahārși Vyāsa. Dalam jaman kemudian ajaran dalam Mìmāmsā sutra dikomentari oleh para pengikutnya seperti : Sabarasvāmin sekitar abad ke-4 Masehi, Bhavanatha Miśra, Nilakanțha, Raghavānanda dan Prabhàkara sekitar tahun 650 Masehi, serta yang terakhir oleh Kumàrila Bhata sekitar tahun 700 Masehi. Purwa Mìmāmsā atau yang lebih dikenal dengan mimamsa, adalah penyelidikian ke dalam bagian yang lebih awal dari kitab suci Veda; suatu pencarian kedalam ritual-ritual Veda atau bagian Veda yang berurusan dengan masalah Mantra dan Brahmana saja.

Mìmāmsā sebenarnya bukanlah cabang dari suatu sistem filsafat, tetapi lebih tepat kalau disebutkan sebagai suatu sistem penafsiran Veda dimana diskusi filosofisnya sama dengan semacam ulasan kritis pada Brahmana atau bagian ritual dari Veda, yang menafsirkan kitab Veda dalam pengertian berdasarkan arti yang sebenarnya. Sebagai filsafat Mìmāmsī mencoba menegakkan keyakinan keagamaan Weda. Kesetiaan atau kejujuran yang mendasari keyakinan keagamaan Veda terdiri dari bermacam-macam unsur, yaitu: 1) Percaya dengan adanya roh yang menyelamatkan dari kematian dan mengamati hasil dari ritual di sorga. 2) Percaya tentang adanya kekuatan atau potensi yang melestarikan dampak dari ritual yang dilaksanakan. 2) Percaya bahwa dunia adalah suatu kenyataan dan semua tindakan yang kita lakukan dalam hidup ini bukanlah suatu bentuk illusi.

Ajaran Mìmāmsā bersifat pluralistis dan realistis yang mengakui jiwa yang jamak dan alam semesta yang nyata serta berbeda dengan jiwa. Karena sangat 
mengagungkan Veda, maka Mìmāmsā menganggap Veda itu bersifat kekal dan tanpa penyusun, baik oleh manusia maupun oleh Tuhan. Apa yang diajarkan oleh Veda dipandang sebagai suatu kebenaran yang mutlak. Menurut filsafat Mìmāmssā, pelaksanaan upacara keagamaan adalah semata-mata perintah dari Veda dan merupakan suatu kewajiban yang mendatangkan pahala. Kekuatan yang mengatur antara pelaksanaan upacara tersebut dengan pahalanya disebut apurwa.

Mengenai Jiwa, Mìmāmsā menyatakan bahwa jiwa itu banyak dan tak terhingga, bersifat kekal, ada dimana-mana dan meliputi segala sesuatu. Karena adanya hubungan antara jiwa dengan benda, maka jiwa mengalami awidya dan kena Karmawesana.

\subsection{Pokok-Pokok Ajaran Mìmāàmsā}

Mìmāmsā pada dasarnya terdiri dari dua aliran yaitu Pūrva Mìmāmsā dan Uttara Mìmāmsā. Mìmāmsā tergolong Sad Darśana yang benar-benar mendasarkan ajarannya pada kitab Veda. Pūrva Mìmāmsā menguraikan bagian pertama dari kitab Veda yaitu kitab Brahmana. Sedang Uttara Mìmāmsā menguraikan bagian kedua yaitu kitab Upanisad. Dari kedua aliran dalam Mìmāmsā tersebut maka yang akan dibicarakan disini hanyalah Pūrva Mìmāmsā atau Karma Mìmāmsā yang dalam uraian selanjutnya akan disebut Mìmāimsā saja. Sedangkan Uttara Mìmāmsā akan dibicarakan dalam bab tersendiri yaitu pada uraian Vedānta. Mìmāmsā disebut Karma Mìmāimsā karena dalam prakteknya sangat menekankan karma yaitu pelaksanaan upacara agama untuk mencapai tujuan.

Oleh karena itu maka dalam perkembangan selanjutnya terjadilah dua aliran dalam Mìmāmsā yaitu disatu pihak adalah pengikut Prabhakara dan yang kedua adalah pengikut Kumarila Bhata. Kedua aliran ini tetap berpegangan pada pokok ajaran Mìmāmsā walaupun tujuan mereka masing-masing ada perbedaan (Tim Penerjemah, $1990: 24$ ).

Mìmāmsā sebenarnya bukanlah cabang dari suatu filsafat, tetapi lebih tepat kalau disebutkan sebagai satu sistem penafsiran Veda di mana diskusi filosofisnya sama dengan semacam ulasan kritis pada bagian ritual dari Veda. Mìmāmsā menafsirkan Veda dalam pengertian berdasarkan arti yang sebenarnya. Pokok pembicaraan dalam Mìmāmsā ialah pengukuhan kewibawaan Veda yang menekankan pada bagian upacara atau Ritualnya. Oleh karena itu Mìmāmsā sering disebut Karma atau Dharma Mìmāmsā. Mìmāmsā berkembang dari aspek ritual Veda dengan obyek sasarannya adalah untuk membentuk dan menopang praktek keagamaan, yaitu melalui dua cara yaitu :

a. Memberikan metode interprestasi dan penjelasan terhadap aturanaturan hukum Veda yang menyangkut ritual, sehingga dapat dimengerti, diselaraskan dan diikuti tanpa kesulitan.

b. Memberikan pertimbangan filosofis dari kepercayaan-kepercayaan dalam hal mana ritual itu tergantung.

Sebagai filsafat Mìmāmsā mencoba menegakkan keyakinan pada Veda dengan beberapa cara antara lain : 
a. Percaya dengan Roh yang menyelamatkan dari kematian dan menikmati hasil dari Ritual di Surga.

b. Percaya dengan adanya kekuatan atau potensi yang dapat melestarikan dampak dari Ritual yang dilaksanakan.

c. Percaya bahwa dunia adalah suatu kenyataan dan semua tindakan yang kita lakukan dalam hidup ini bukanlah suatu bentuk illusi (Surada, 2005 : 77).

\subsubsection{Metafisika Mìmāms $\bar{a}$}

Metafisika adalah teori ilmu pengetahuan yang mengupas tentang problema umum mengenai kebenaran hakekat manusia, alam semesta dan Tuhan, adapun metafisika dari ajaran Mìmāmssā adalah sebagai berikut ini:

\section{1) Apūrva dan Śakti}

Yang menjadi tujuan pokok Mìmāimsā adalah : menyusun aturan dan teknik untuk menerangkan ajaran Veda terutama tentang pelaksanaan dharma. Sütra pertama dari Mìmāmsā berbunyi: "Athato Dharmajijñasa" (satu keinginan untuk mengetahui dharma). Yang dimaksud dengan Dharma disini ialah kewajiban yang terkandung dalam pelaksanaan upacara-upacara keagamaan yang bersumber pada Veda, termasuk pula tuntunan kesusilaan. Dalam prakteknya Mìmāms $\bar{a}$ sangat mengutamakan kesusilaan karena dinyatakan bahwa orang yang kotor secara kesusilaan sangat sukar dibersihkan melalui Veda. Kebersihan dalam kesusilaan merupakan syarat mutlak didalam pelaksanaan upacara karena kebersihan itu dapat menyebabkan berhasilnya upacara korban dan dapat memberikan pahala yang diharapkan (Maswinara, 1998 : 55).

Mengenai pahala dari suatu koban di ajarkan pahala itu tidak dapat segera setelah selesai upacara korban itu, melainkan menunggu beberapa waktu. Apalagi pahala dari suatu korban itu termasuk pahala tertinggi misalnya sorga, maka pahala itu akan diterima pada akhir kehidupan yaitu setelah orang meninggal dunia dan pahala tertinggi diterima di akhirat.

Dharma yang dilakukan sekarang dengan hasilnya diterima kemudian diterangkan dalam ajaran Apürva (Apürva berarti tenaga yang tidak tampak). Menurut Rși Jaimini Apürva memberikan ganjaran pada si pelaksana kurban, karena Apūrva merupakan mata rantai atau hubungan yang diperlukan antara kerja dengan hasilnya. Apürva adalah Arșța yang merupakan kekuatan-kekuatan yang tidak terlihat yang sifatnya positif dan diciptakan oleh kegiatan itu sendiri, yang akan membawa pada pencapaian buah perbuatan.

Dalam ajaran ini dinyatakan tenaga (daya/kekuatan) dalam jìva orang yang berkorban. Apūrva (tenaga) ini lah yang bertahan dan terus mengatur serta berhubungan dengan buahnya sampai buahnya itu masak. Jadi Apūrva (tenaga) itu menjadi jembatan yang menghubungkan Dharma (korban) dengan buahnya sehingga buah itu tetap dapat dipetik oleh yang melakukan korban. 
Menurut Mìmāmsā setiap benda di alam semesta ini mempunyai suatu kekuatan tertentu yang ada di dalamnya. Kekuatan itu disebut dengan Śakti yang tidak dapat dilihat dengan mata. Contoh : Sebuah benih kacang akan dapat tumbuh menjadi kecambah dan berkembang apabila memiliki suatu kekuatan di dalamnya. Biji itu tidak akan dapat tumbuh apabila ada sesuatu yang mengganggu sehingga biji rusak. Ini berarti ada hubungan yang erat antara benda (biji kacang) dengan kekuatan (Śakti) yang ada di dalamnya. Demikian juga kekuatan untuk membakar dan menerangi dari api, kekuatan membasahi dari air dan lain sebagainya (Surada, $2005: 80$ ).

\section{2) Alam Semesta}

Berbicara mengenai alam semesta Mìmāmsā mengatakan bahwa alam ini riil dan kekal serta terjadi dari atom-atom yang kekal pula. Atom-atom tidak membutuhkan pengaturan dari Tuhan di dunia ini, melainkan diatur oleh hukum karma. Alam ini tidak dibuat oleh Tuhan karena alam ini ada dengan sendirinya. Tidak ada penciptaan dan penghancuran dunia ini, melainkan dunia ini kekal adanya. Jaimini tidak percaya akan penciptaan alam semesta ini dan hanya mempercayai akan drajat kebahagiaan di surga dan pada Saācara (perilaku yang benar), Satyamvada (berbicara yang benar) dan Dharmācara (melaksanakan kewajiban). Kedua aliran Mìmāmsā baik Prabhàkara maupun Kumārila Bhatta sama-sama mengajarkan adanya empat unsur di alam ini yaitu : Dravya (Substansi), Guṇa (Kwalitas), Karma (Aktifitas) dan Samānya (Sifat umum).

Draoya (Substansi) menurut Prabhkāra terdiri dari sembilan (9) yaitu : 1) Prthivī (Bumi). 2) Āpah (Air). 3) Teja (Api). 4) Bāyu (Hawa / udara). 5) $\bar{A} k \bar{a} s ́ a$ (Ether / Angkasa). 6) Manas (Akal / pikiran). 7) Dik / Dis (Ruang). 8) Kāla (Waktu) dan 9) Jìva (Pribadi) (Maswinara, 1998 : 58). Sedangkan Kumàrila Bhatta mengajarkan ada 11 (sebelas) bagian Dravya (Substansi) yaitu 9 (sembilan) yang diajarkan oleh Prabhākara ditambah lagi dua yaitu: Tamasa (Kegelapan) dan Śabda (Suara). Dravya (Substansi) itu adalah sesuatu yang dapat diamati karena terdiri dari atom-atom yang dapat diamati seperti debu halus yang tampak dalam sinar matahari. Dravya (Substansi), Guna (Kwalitas), dan Samānya (Sifat umum) sesungguhnya tidak dapat dipisahkan dan dibedakan secara mutlak walaupun ketiganya itu sebenarnya berbeda karena ketiga-tiganya mewujudkan satu kesatuan yang bulat. Contoh : Daun itu hijau dan berfungsi sebagai alat potosintesis. Daun dengan warna hijaunya dan sifat umumnya tidak dapat dipisahkan secara mutlak dan ketiganya itu mewujudkan satu kesatuan yang bulat sehingga menampakkan suatu benda.

Sesungguhnya kategori-kategori itu tidak dapat dipisah-pisahkan, memang ada kesamaan di antara kategori-kategori itu, namun kesamaan itu terdapat pada perbedaan-perbedaannya. Dapat dikatakan bahwa semuanya mewujudkan kesamaan di dalam perbedaan atau benda-benda. Adanya kesamaan kualitas dengan substansi, maka kita dapat menyebutkan kualitas dari substansi itu, misalnya "bunga merah adalah merah". Bila kita renungkan tentulah substansi tidak sama dengan 
kualitas secara mutlak. Contoh: "mawar tidaklah sama dengan merah". Akan tetapi tidak benar pula untuk mengatakan bahwa substansi secara mutlak berbeda dengan kualitas, misalnya "mawar tidak dapat dibedakan secara mutlak dengan merahnya". Keduanya secara bersama-sama mewujudkan satu kesatuan, yaitu dimana ada mawar di situ ada merah.

\section{3) Veda dan Tuhan}

Mìmāmsā mendasarkan ajarannya pada kitab suci Veda dan Veda diakui sebagai sumber pengetahuan yang maha sempurna. Veda itu apaurusya yaitu bukan hasil karya manusia karena Veda itu amat sempurna sedangkan manusia tidak sempurna adanya. Walaupun demikian Veda pula bukan ciptaan Tuhan karena Veda telah ada tanpa ada yang mengadakan dan Veda ada dengan sendirinya serta bersifat kekal abadi. Kebenaran Veda mancakup kebenaran di dunia yang nyata ini dan di dunia yang tidak tampak oleh manusia.

Menurut Rși Jaimini Veda secara praktis hanyalah Tuhan semata, dan Veda yang abadi tersebut tidak memerlukan dasar apapun untuk sandarannya. Tidak ada wahyu Tuhan, karena Veda itu sendiri merupakan otoritasnya, yang merupakan satu-satunya sumber dari Dharma. Veda sebagai śabda adalah kekal. Veda menyatakan dirinya sendiri dan memiliki kebenaran di dalam dirinya sendiri. Dalam Mìmāmsā tidak diperlukan adanya Tuhan. Mìmāmsia tidak percaya adanya Tuhan yang kekuasaanNya berada di atas atau minimal setara dengan Tuhan. Dharma yang diperintahkan oleh kitab suci Veda dikenal sebagai Śruti yang pelaksanaannya memberikan kebahagiaan. Apabila terjadi perbedaan antara Śruti dan Smrti, maka kitab Smrti dapat diabaikan, termasuk kebiasaan-kebiasaan orang-orang suci yang munculnya belakangan.

Mìmāmsā tak dapat memuaskan orang-orang bijak dan mereka yang cerdas; karena itu para pengikut Mìmāmsā yang belakangan secara perlahan-lahan memasukkan Tuhan. Mereka menyatakan bahwa Apūroa yang tanpa memiliki kesadran dan kecerdasan tan dapat memberikan ganjaran. Bila upacara kurban yang dilaksanakan untuk menghormati keberadaan tertinggi (Tuhan), ia akan membawa pada pencapaian kebaikan tertinggi, Apùrva tak dapat berbuat apa-apa kecuali ia digerakkan oleh Tuhan.

Semua pekerjaan seharusnya dilaksanakan sebagai suatu persembahan kepada Tuhan sebagai Keberadaan Yang Tertinggi, sehingga memungkinkan untuk mendapatkan pembebasan. Apabila upacara kurban yang dilakukan tanpa perasaan, śraddha (keyakinan) dan bhakti (kepatuhan), maka hasil yang dicapai tak akan dapat membantu seseorang untuk mencapai kelepasan. Yang dikehendaki sebenarnya oleh Mìmāmssa adalah pengurbanan kepantingan sendiri, keakuan, rasa sukadan benci (rāga-dveśa) dan bukan upacara kurban itu sendiri (Surada, $2005: 81$ ). 


\section{4) Hukum Karma}

Walaupun Mìmāimsā tidak mengajarkan hakekat hukum karma seperti halnya dalam Agama Hindu, namun Mìmāmsā yakin akan adanya sebab-akibat atau pahala dari suatu perbuatan. Mìmāmsā mengajarkan bahwa hukum karma merupakan hukum moril yang mengatur dunia beserta isinya. Apa yang terjadi di dunia ini adalah merupakan akibat dari karma terdahulu. Oleh karena itu maka apa yang akan menimpa dunia ini seolah-olah sudah ditentukan oleh hukum moril itu. Makhluk dan manusia tidak dapat membantah dan menentang serta lari dari kenyataan yang dia alami, karena semua itu adalah pahala dari karma terdahulu. Atas dasar itu maka diajarkan bahwa untuk mewujudkan kebaikan dan ketentraman di masa datang maka amat perlu berbuat kebaikan dan kebenaran pada masa hidup ini. Karma yang baik itu yalah perbuatan yang dilandasi oleh ketentuan yang diajarkan oleh Veda yaitu : Dharma (upacara korban). Dan upacara korban itu hendaknya dilakukan dengan semangat tinggi, penuh kesadaran, tulus hati dan tidak mengharapkan imbalan berupa buahnya.

Menurut Mìmāmsā seseorang hendaknya menjalani kehidupannya sesuai dengan aturan Veda dimana ia harus melaksanakan nityakarma, naimitika karma selama ada kesempatan untuk mendapatkan pembebasan yang dapat dikatakan sebagai kewajiban tanpa syarat. Bila ia lalai melakukannya, maka akan terkena dosa kelalaian (pratyavāya dosa). Ia melakukan kamya karma untuk mencapai tujuan akhir yang istimewa. Bila ia dapat menghindari perbuatan yang dilarang (nisiddhakarma), ia akan terhindar dari naraka dan bila ia dapat melaksanakan kewajiban tanpa syarat itu, akan dapat mencapai kelepasan. Demikianlah hukum karma yang diajarkan oleh Mìmāmssā.

\subsubsection{Epistemologi Mīmāmis $\bar{a}$}

Epistemologi yaitu teori ilmu pengetahuan yang mengungkapkan sifat pengetahuan manusia sendiri, bagaimana dia berkembang dan seberapa jauh dia mampu menjangkau kebenaran itu sendiri. Mengenai alat atau cara untuk mendapatkan pengetahuan yang benar Prabhākara mengajar lima cara, sedangkan Kumārila Bhatta mengajarkan enam cara termasuk yang diajarkan oleh Prabhākara. Keenam cara itu ialah : 1) Pratyaksa (Pengamatan langsung). 2) Anumāṇa (Penyimpulan). 3). Śabda (Kesaksian). 4) Upamāna (Pembandingan). 5) Arthāpatti (Persangkaan). 6) Anupalabdhi (Ketiadaan).

\subsubsection{Etika Mìmāàms $\bar{a}$}

Etika ilmu yang mendalami problema-problema moral, seperti pedoman tentang pertimbangan moral, tujuan akhir hidup manusia dan problemaproblema yang menyangkut kesadaran manusia. Adapun etika dari ajaran filsafat Mìmāmsā adalah sebagai berikut ini:

1) Jiwa (Ātma)

Makhluk-makluk yang hidup di dunia ini terutama manusia dipandang berjiwa oleh Mìmāmsā. Oleh karena makhluk (manusia) berjumlah amat banyak jīva itupun banyak adanya. Atas dasar itu maka 
Mìmāms $\bar{a}$ menganut sistem pluralis dan realistis. Mìmāms $s \bar{a}$ mengakui dan percaya dengan banyak realitas seperti kenyataan adanya energi, moral, surga, naraka dan lain sebagainyayang tidak dapat diketahui melalui pengalaman indriya. Mìmāmsā mengakui dan percaya adanya banyak jīoa dan dunia yang nyata, tetapi keduanya berbeda. Átma (jīva) berjumlah tak terbatas dan ada dimana-mana serta kekal. Tiap-tiap tubuh makhluk yang hidup memiliki satu jīva.

Menurut Jaimini, Jivo atau Sang Diri adalah Cetana yaitu gabungan dari kecerdasan dan tanpa kesadaran. Jivoa atau Sang Diri jumlahnya tak terhingga yang merupakan si pelaku dan si penikmat dan meresapi segalanya. Badan merupakan tempat untuk mengalami sedangkan indriaindria adalah pelatan untuk menikmati dan mengalami. Jiva atau Sang Diri akan dapat merasakan apabila ia menyatu dengan pikiran (manas). Jìva atau Sang Diri bukanlah indria-indria, karena ia tetap ada walaupun indria-indria dihancurkan, sedangkan badan terbuat dari materi dan merupakan pelayan bagi Jĩva atau Sang Diri.

Menurut pandangan Mìmāmsā Jì̃a adalah sebagai substansi, keadaannya berbeda dengan Tubuh, Indriya dan Budhi. Semua Jĩva memiliki kesadaran, bersifat kekal berada dimana-mana dan meliputi segala sesuatu. Walapun Jiva tak dapat diamati, namun senantiasa mernjadi pelaksana segala pengethuan.

Jivoa merupakan subyek dan obyek pengetahuan. Jivoa itu adalah kesadaran sehingga mampu Jiva itu sebagai subyek pengetahuan. Dan sebagai obyek pengetahuan maka Jìva itu perlu dimengerti., dirasakan dan disadari oleh makhluk (manusia) itu sendiri. Karena Jìva itu adalah kesadaran dalam diri manusia, maka Jiva-lah yang mengendalikan tubuh manusia untuk mendapatkan kelepasan. Hubungan indriya dengan Jìva $(\bar{A} t m a)$ sangat erat karena indriya merupakan alat untuk mengenal dunia luar yang selalu di kendalikan oleh Jiva. Apapun yang diketahui oleh indriya, maka Jiva pun mengetahui.

\section{2) Mokșa (Kelepasan)}

Rși Jaimini tidak mempercayai adanya mokșa dan hanya mempercayai keberadaan Surga, yang dapat dicapai melalui Karma atau Kurban. Pelaksanaan kegiatan yang diajarkan oleh Veda merupakan sādhanā atau cara pencapaian Surga. Penyebab terbelenggunya Jiva adalah kegiatankegiatan tang dilarang oleh Karma Kanda merupakan bagian dari Veda. Jadi pokok ajaran Rși Jaimini adalah "laksanakanlah upacara kurban dan nikmati hasilnya di Surga"

Prabhākara dan Kumārila Bhatta, tak dapat menghindari tentang masalah perbebasan akhir, karena ia menarik perhatian para pemikir filsafat lainnya. Prabhākara menyatakan bahwa penghentian mutlak dari badan yang disebabkan hilangnya Dharma dan Adharma secara total, yang disebabkan oleh kelahiran kembali merupakan kelepasan atau pembebasan mutlak, karena hanya dengan Karma saja tak akan dapat mencapai pembebasan akhir. Oleh karena itu diperlukan pengetahuan 
yang sesungguhnya tentang Sang Diri yang dapat menghalangi timbunan Karma yang dapat membebaskan dirinya dari kelahiran kembali.

Pandangan Kumārila Bhatta mendekati pandangan Advaita Vedānta yang menyatakan bahwa Veda disusun oleh Tuhan dan merupakan Brahman dalam wujud suara. Mokșa adalah keadaan yang positif baginya yang merupakan realisasi dari Ātman. Kumārila Bhatta berpendapat bahwa pengetahuan tidak cukup guna untuk mencapai kebebasan, tetapi harus digabungkan dengan kegiatan / kerja (Karma).

Mìmāmsā mengajarkan bahwa tujuan hidup terakhir manusia yalah mendapatkan mokṣa (kelepasan). Mìmāmsā mengakui pula adanya alam neraka sebagai tempat Jiva manusia yang selalu berbuat melanggar dharma (Maswinara, 1998 : 59).

Sebagai jalan untuk mendapatkan kelepasan Mìmāmsā mengajarkan hendaklah manusia dalam hidupnya senantiasa melakukan dharma yaitu upacara keagaam dengan benar yang dilandasi oleh ketentuan Veda, dan sedapat mungkin menjauhkan diri dari segala bentuk tindakan yang bertentangan dengan Veda. Bila ternyata jiva yang kekal itu mengalami sengsara setelah menusia meninggal dunia maka jalan yang patut ditempuh untuk membebaskan jiva itu dari kesengsaraan adalah mengadakan upacara korban terhadap jīva itu. Karena upacara korbanlah yang dapat membersihkan dan membebaskan jīva dari kesengsaraan.

Sedangkan di lain pihak bila orang tidak melakukan upacara korban keagamaan, ini berarti secara perlahan-lahan mereka telah merusak hidupnya dan tidak akan mendapatkan kelepasan. Melainkan sebaliknya hanya neraka alam yang akan ditempati oleh jīva-nya kelak (Surada, 2005 : 86).

\subsection{Pengaruh Darśana terhadap Agama Hindu di Bali}

Berdasarkan uraian tersebut di atas dapat dikomentari bahwa filsafat Hindu dapat dibagi dalam dua golongan besar, yaitu Astika (ortodoks) dan Nastika (Heterodoks). Yang termasuk dalam golongan Astika ada enam aliran filsafat (Sad-darsana) : Mìmāmis̄ā; Vedānta; Sāṁhyyā; Yoga; Nyāya; dan Vaiśesika. Keenam aliran filsafat ini disebut orthodoks, bukan oleh karena penganutnya percaya akan adanya Tuhan, melainkan oleh karena mereka menerima kewenangan kitab-kitab suci Veda. Misalnya aliran Mìmāmsā dan Samikhyā menyangsikan adanya Tuhan sebagai pencipta alam semesta, namun disebut orthodoks (astika), karena menerima wewenang kitab - kitab suci Veda. Dalam golongan Heterodhoks (nāstika) termasuk tiga aliran filsafat (tri-darśana) yaitu Carvaka, Buddha dan Jaina. Disebut demikan karena ketiga aliran ini tidak menerima kewenangan kitab-kitab suci Veda. Perbedaannya adalah, menerima kewenangan kitab-kitab suci Veda atau tidak menerima kewenangan tersebut.

Kitab suci Veda telah memainkan peranan dalam pertumbuhan alam pikiran Hindu . Orang-orang Hindu percaya akan keabadian dan kewenangan kitab-kitab suci Veda ini, sebab kitab-kitab suci ini merupakan literatur yang tertua sebagai sumber-sumber renungan filsafat. 
Aliran Mìmāmsà dan Vedānta dipandang sebagai kelanjutan langsung dari kebudayaan dan peradaban jaman Veda, yang memberi tekanan pada pentinya ritual nyata sebagai eksyen (karma) dalam renungan pemikiran (Jñana). Aliran Mìmāms $\bar{a}$ menekankan penting artinya ritual nyata eksyen dan upacaraupacara, sedangkan aliran Vedānta memberi tekanan pada pentingnya alam renungan pemikiran. Oleh karena keduanya merupakan kelangsungan dari kebudayaan dan peradaban jaman Veda, maka Mìmāmsā juga disebut dengan nama Pūrva-Mìmāimsā atau Karma Mìmāmsā, sedangkan Vedānta dengan nama Uttara-Mìmāìsā atau Jñana- Mìmāmsāa.

Aliran Saṁkhyā, Yoga, Nyāya dan Vaiśesika, walaupun berdasarkan teori teori mereka atas pengalaman-pengalaman manusia biasa dan pemikiranpemikiran manusia sendiri, namun mereka tidak menentang wewenang kitabkitab suci Veda, dan mencoba menyatakan bahwa testament yang terdapat dalam kitab-kitab suci Veda sejalan dengan harmonisnya dengan teori dan pemikiran mereka. Sedangkan aliran filsafat Carvaka, Bauddha dan Jaina menentang wewenang kitab-kitab suci Veda, dan karenanya disebut heterodoks (Nāstika).

Ajaran Hindu bersumber dari Veda yang terdiri dari empat himpunan Veda (Veda Samhitā) yaitu: Rg veda, Sama veda, Yajur veda, dan Atharwa veda. Masing-masing Veda Samhita terdiri dari tiga bagian yaitu mantra, brahmana dan upanisad. Mantra merupakan kumpulan puji-pujian dan doa-doa, brahmana merupakan uraian-uraian tentang upacara, sedangkan upanisad memuat uraianuraian tentang hakikat Pencipta, proses penciptaan dan Ciptaan-Nya.

Uraian-uraian yang terdapat dalam upanisad tersebut masih bersifat global, sehingga pengkhusannya masih memerlukan penafsiran-penafsiran. Hal ini menimbulkan berbagai penafsiran. Masing-masing penafsiran menimbulkan satu aliran filsafat. Dengan demikian maka timbullah berbagai aliran filsafat. Aliran-aliran filsafat tersebut secars garis besarnya dapat dikladifikasikan menjadi enam, Sad Dharsana, yaitu: Vedānta, Nyāya, Waiśesika, Mìmāimsā, Samkkhyā dan Yoga. Aliran Vedānta terbagi lagi atas beberapa sub aliran. Yang paling banyak penganutnya adalah Dwaita Wedanta.

\subsubsection{Pengaruh Mìmāmsā dalam Yajũa di Bali}

Sad Darśana tersebut, yang besar pengaruhnya terhadap pelaksanaan agama Hindu di Bali adalah Mìmāmsà dan Dwaita Vedānta. Filsafat Mìmāmsāa (Mìmāmsā Darśana) sangat besar pengaruhnya terhadap pelaksanaan yadnya di Bali. Menurut filsafat Mìmāmsā tersebut, jalan untuk mencapai kelepasan (moksa) adalah dengan melaksanakan yadnya seperti yang diajarkan oleh kitab $V e d a$. Dalam usaha mencapai kelepasan tidak mungkin bisa tercapai dalam satu kali kelahiran, melainkan harus dicapai secara berangsur-angsur setingkat demi setingkat melalui beberapa kali kelahiran. Setiap kali orang melakukan yajna maka ia akan memperoleh pahala berupa apūrwa, yaitu suatu tenaga atau daya atau energi yang tidak tampak di dalam jiwa orang yang melakukan yadnya. Dengan seringnya orang melakukan yadnya (dihitung sejak kehidupannya yang lalu), maka apurwa tersebut akan mencapai tingkatan kumulatif tertentu, yang dapat membawa jiwa mencapai kelepasan. Konsep apurwa inilah rupanya yang besar pengaruhnya dalam pelaksanaan agama Hindu di Bali. Hanya sayangnya 
konsep yadnya yang diterapkan tampaknya terlalu didominasi oleh upacara. Padahal pengertian yadnya tidak terbatas pada upacara saja. Masih banyak bentuk yadnya yang lain, seperti berdana punia, berjapa, membaca ajaranajaran keagamaan (wandanam) dan sebagainya.

Filsafat Dvaita Vedānta mempengaruhi pandangan masyarakat Bali tentang hakikat Hyang Widhi, dewa, gandarwa, yaksa, atma (dalam pengertian Bali sama dengan roh yang sudah meninggalkan badan kasar), bhuta, pisaca, alam semesta (bhuwana agung) dan manusia (bhuwana alit). Menurut filsafat Dvaita Vedānta, Brahman (Tuhan) merupakan kenyataan tertinggi yang tiada berawal dan tiada berakhir, yang serba maha, dan merupakan sebab pertama dari segala sesuatu. Alam semesta beserta isinya tidak diciptakan sekaligus, melainkan secara berangsur-angsur melalui proses evolusi. Yang mula-mula diciptakan adalah Purusa dan Prakerti. Prakerti adalah zat kebendaan yang tidak memiliki kesadaran dan merupakan embrio dari alam semesta. Dari Prakerti muncul Pañca Tan Matra. Dari Pañca Tan Matra muncul Pañca Mahabhuta dan dari Pañca Mahabhuta maka terbentuklah alam semesta atau bhuwana agung atau makrokosmos.

\subsubsection{Zat Kesadaran}

Purusa merupakan zat kesadaran. Purusa yang diciptakan oleh Tuhan jumlahnya banyak sekali, masing-masing berdiri sendiri dan mempunyai sifatsifat yang mendekati sifat-sifat Tuhan, seperti sangat tahu (bukan maha tahu), sangat sakti, sangat kasih, dan sebagainya. Selama proses berlangsungnya evolusi alam semesta, sebagian dari purusa tersebut kesadarannya menurun, sehingga terbelenggu oleh prakerti. Purusa yang terbelenggu oleh prakerti itulah yang menjadi mahkluk-mahkluk hidup dalam segala jenis dan tingkatannya yang mengisi alam semesta ini, antara lain manusia. Manusia juga disebut bhuwana alit atau mikrokosmos, karena semua unsur alam semesta terdapat pada manusia dalam ukuran kecil.

Tingkatan-tingkatan makhluk hidup yang terjadi tersebut tergantung kepada besar kecilnya penurunan kesadaran purusa yang terbelenggu. Makin besar penurunan kesadarannya, makin rendahlah tingkatan makhluk yang terjadi. Makhluk yang berada di bawah tingkatan manusia mengalami evolusi dari kelahiran ke kelahiran berikutnya, mengikuti hukum rta (hukum alam semesta) hingga mencapi tingkatan manusia.

Setelah mencapai tingkatan manusia akan terbuka beberapa kemungkinan. Bisa berevolusi terus sampai mencapai moksa, bisa terikat terus dalam siklus samsara, tetapi bisa pula terjadi regresi, yaitu terlahir kembali sebagai makhluk yang berada di bawah tingkatan manusia. Evolusi atau samsara atau regresi yang dialaminya tergantung kepada karma-wasananya.

\subsubsection{Bertingkat-tingkat}

Setelah purusa-purusa tersebut mengalami evolusi/samsara/regresi, maka purusa menjadi bertingkat-tingkat, yang pada prinsipnya dapat diklasifikasikan atas tiga tingkatan.

1) Nitya Purusa, yaitu purusa yang tidak pernah terbelenggu oleh prakerti. Nitya Purusa ini adalah para Dewa. 
2) Mukti Purusa, yaitu purusa yang pernah dibelenggu oleh prakerti, tetapi sudah mencapai kelepasan. Misalnya roh orang-orang suci yang sudah mencapai kelepasan.

3) Banda Purusa, yaitu purusa yang masih terikat oleh prakerti. Banda Purusa ini dibedakan lagi atas tiga jenis yaitu: Sida Purusa, masih terkena pengaruh prakerti, tetapi sudah tidak terikat lagi dengan proses samsara. Samsarin Purusa, masih terikat kepada proses samsara. Samsarin purusa ini adalah jiwa manusia pada umumnya. Terakhir, Tamo Purusa, yang masih berada pada tingkatan yang rendah. Tamo Purusa ini adalah roh tumbuh-tumbuhan, roh binatang dan roh makhluk-makhluk tingkat rendah (diadaptasi dari http://www.network54.com /Forum/ 178267).

\subsubsection{Catur Marga}

Ajaran Catur Marga yang kita kenal sekarang, tiga yang pertama yaitu Jñana Marga, Karma Marga dan Bhakti Marga berasal dari Dwaita Vedānta, yang disebut Tri Marga. Sedangkan marga yang keempat dari Catur Marga berasal dari Yoga Dharsana. Menurut Dwaita Wedanta, ketiga jalan tersebut tidak boleh hanya dipilih salah satu saja. Ketiganya harus dijalani secara sinergis, sebab segala perbuatan (karma) haruslah berdasarkan pengetahuan. Sebaliknya pengetahuan yang tidak diamalkan akan tidak ada gunanya. Mencari pengetahuan dan melakukan sesuatu perbuatan akan lebih afdol kalau disertai rasa bakti.

Umat Hindu di Bali pada masa lalu, lebih memilih Karma Marga tanpa diajarkan tentang Jñana-nya. Sedangkan Jñana Marga hanya dikuasai oleh kaum pendeta saja. Imbauan untuk kembali ke Veda, hendaknya jangan diartikan secara sempit. Kembali ke Veda tidak berarti kita hanya melaksanakan yang tercantum dalam Veda dan meninggalkan warisan budaya yang luhur. Kalau kembali ke Veda diartikan secara sempit, yaitu hanya melaksanakan apa yang terdapat dalam Veda, maka candi, pura, tari rejang, baris, canang gebogan dan sebagainya tidak diperlukan. Kembali ke Veda bukan dalam arti sempit seperti itu. Kembali ke Veda berarti pelurusan terhadap tradisi-tradisi yang menyimpang dari Veda. Sedangkan tradisi-tradisi dan aspek budaya lainnya yang cocok atau yang mendukung ajaran Veda perlu kita lestarikan.

\section{PENUTUP}

Darśana berarti pandangan tentang kebenaran. Darśana ada sembilan disebut Nava Darśana, yaitu Nyāya, Vaiśesika, Sāmkhyāa, Yoga, Mìmāṁsā, Vedānta, Buddha, Jaina dan Carvāka. Ajaran Nyāya, Vaiśesika, Sāmikhyā, Yoga, Mìmāmssā, dan Vedānta, berdasarkan teori - teori atas pengalaman-pengalaman manusia biasa dan pemikiran-pemikiran manusia sendiri, namun mereka tidak menentang wewenang kitab Veda karena disebut astika (ortodok), dan mencoba menyatakan bahwa testament yang terdapat dalam kitab Veda. Sedangkan aliran filsafat Carvaka, Buddha dan Jaina menentang wewenang kitab-kitab suci Veda, dan karenanya disebut heterodoks (nāstika).

Mìmāmsā sangat besar pengaruhnya terhadap pelaksanaan yajña Agama Hindu di Bali. Mìmāmssā mengajarkan jalan untuk mencapai kelepasan (mokșa) 
adalah dengan melaksanakan yajña seperti yang diajarkan oleh kitab Veda. Dalam usaha mencapai kelepasan tidak mungkin bisa tercapai dalam satu kali kelahiran, melainkan harus dicapai secara berangsur-angsur setingkat demi setingkat melalui beberapa kali kelahiran. Setiap kali orang melakukan yajña maka ia akan memperoleh pahala berupa apürwa, yaitu suatu tenaga atau daya atau energi yang tidak tampak di dalam jiwa orang yang melakukan yajña. Dengan seringnya orang melakukan yajña, maka apürwa tersebut akan mencapai tingkatan kumulatif tertentu, yang dapat membawa jiwa mencapai kelepasan.

Ajaran Catur Marga yang dikenal sekarang, tiga yang pertama yaitu Bhakti Marga, Karma Marga dan Jñana Marga, berasal dari Dwaita Vedānta, yang disebut Tri Marga. Sedangkan Raja marga yang keempat dari Catur Marga berasal dari Yoga Darsana. Dwaita Vedanta mengajarkan, ketiga jalan tersebut tidak boleh hanya dipilih salah satu saja. Ketiganya harus dijalani secara sinergis, sebab segala perbuatan (karma) haruslah berdasarkan pengetahuan. Sebaliknya pengetahuan yang tidak diamalkan akan tidak ada gunanya. Mencari pengetahuan dan melakukan sesuatu perbuatan akan lebih afdol kalau disertai rasa bakti.

\section{DAFTAR PUSTAKA}

Chatterjee and Datta, 1984, An Introduction to Indian Philosophy. India: Calcutta University Press.

Chandradhar Sharma, 1997. A Critical Survey of India Philosophy. India: Motical Banarsidass Publisher Private Limited Delhi.

Maswinara, I Wayan. 1998. Sistem Filsafat Hindu. Surabaya: Paramita.

Nila, K. 1989. “Maha Nirwana Tantra (Arthur Avalon' Tantra of Great Liberation)" Denpasar: Keperluan Sendiri.

Tim Penerjemah. 1990. Tattwa Darsana I, II \& III. Jakarta: Yayasan Dharma Sarathi.

Sumawa, I Wayan dan Tjokorda Raka Krisnu. 1996. Materi Pokok Darsana. Jakarta: Universitas Terbuka.

Sura. 1999. "Siwa Tattwa". Denpasar : Milik Pemerintah Propinsi Bali, Peningkatan Sarana Prasarana Kehidupan Beragama.

Sura. 1991. Agama Hindu Sebuah Pengantar. Denpasar: CV Kayumas Agung.

Sura. 1991. Pengantar Veda dan Upanisad. Denpasar.

Surada, I Made. 2005. "Darśana". Denpasar: Institut Hindu Dharma Negeri Denpasar.

Vatsyayan. 1997 - 1998. Indian Philosophy. India: Kedaranath Ram nanth, Meerut. 